\title{
POLA PENGASUHAN REMAJA PADA KELUARGA BURUH MIGRAN INDONESIA (BMI) UNTUK MEWUJUDKAN GENERASI BERKUALITAS DI KECAMATAN PENGANTENAN-PAMEKASAN
}

\author{
Netty Dyah Kurniasari, Teguh Hidayatul Rachmad, Diyah Herowati, Iswari \\ Srihastuti \\ nettyutm@gmail.com,teguhkaneshiro@gmail.com,didihero@yahoo.com, iswarihariastuti@yahoo.com \\ Prodi Ilmu Komunikasi, Fakultas Ilmu Sosial dan Ilmu Budaya, BKKBN Provinsi Jawa Timur
}

\begin{abstract}
ABSTRAK
Remaja adalah titik awal kehidupan untuk meraih masa depan yang cerah. Keputusan yang salah berakibat fatal dalam karir dan reputasi di masyarakat. Peran orang tua dalam mengarahkan dan mengasuh anaknya yang remaja menjadi point penting agar tetap di jalur yang positif. Permasalahan yang terjadi apabila anak-anak yang sudah menjelang remaja menjadi bagian dari keluarga buruh migran Indonesia (BMI). Pola asuh tidak diberikan sepenuhnya kepada orang tua kandung, namun diserahkan kepada kakek/nenek atau saudara yang diberikan kepercayaan oleh orang tua untuk mengasuhnya. Pola asuh pada keluarga migran Indonesia di kecamatan Pengantenan-Pamekasan menerapkan pola asuh situasional, dimana orang tua asuh pengganti membuat strategi untuk mengasuh dengan cara demokratis, otoriter dan permisif. Cara pola asuh seperti ini terbilang sukses, karena remaja yang ditinggal oleh orang tuanya menjadi buruh migran Indonesia tidak mengalami beban psikologis.
\end{abstract}

Kata kunci : pola asuh remaja, buruh migran Indonesia kecamatan Pengantenan-Pamekasan,

\section{ABSTRACT}

Teenagers are the starting point of life to achieve a bright future. Wrong decisions are fatal in career and reputation in society. The role of parents in directing and nurturing their teenage children is an important point to stay on a positive track. Problems that occur when children who have approached adolescence become part of the family of Indonesian migrant workers. Parenting is not given entirely to biological parents, but is left to grandparents or relatives who are given the trust by parents to care for them. The upbringing of Indonesian migrant families in PengantenanPamekasan sub-district applies situational parenting, where substitute foster parents develop strategies to nurture democratic, authoritarian and permissive ways. This way of parenting was a success, because the teenagers who were left behind by their parents to become Indonesian migrant workers did not experience a psychological burden.

Keywords: teenage upbringing, Indonesian migrant workers Pengantenan-Pamekasan sub-district,

\section{PENDAHULUAN}

\section{A. Latar Belakang Masalah}

Pola asuh orang tua merupakan interaksi antara anak dengan orang tua selama mengadakan kegiatan pengasuhan. Pengasuhan ini orang tua mendidik, mem- bimbing, dan mendisiplinkan serta melindungi anak untuk mencapai kedewasaan sesuai dengan norma-norma yang ada dalam masyarakat (Dekrita, 2005). Pola Asuh menurut agama adalah cara memperlakukan anak sesuai dengan ajaran agama berarti memahami anak dari berbagai aspek, dan 
memahami anak dengan memberikan pola asuh yang baik, menjaga anak dan harta anak yatim, menerima, mamberi perlindungan, pemeliharaan, perawatan dan kasih sayang sebaik -baiknya (QS Al Baqoroh: 220). Meski banyak TKI yang menghadapi kemalangan tetap saja banyak orang tergiur menjadi TKI di luar negeri. Himpitan kemiskinan, kesulitan hidup, sulitnya mendapatkan pekerjaan dan pendapatan yang layak di dalam negeri, dan harapan perbaikan nasib, membuat mereka tetap nekat. Apalagi tidak ada jaminan apapun bagi mereka atas pemenuhan kebutuhan pokok mereka, juga jaminan kesehatan, pendidikan dan keamanan. Masa depan anak akan sangat tergantung dari pengalaman yang didapatkan termasuk faktor pendidikan dan pola asuh orang tua. Kepentingan mereka sendiri dengan dalih untuk kesejahteraan anak, sehingga terkadang peran mereka sebagai orang tua yaitu mendidik dan mengasuh anak terlalaikan. Tidak hanya kebutuhan fisik saja tetapi kebutuhan psikologis juga menentukan perkembangan anak ke arah remaja yang mantap dan menyeluruh. Di saat sekarang ini tidak sedikit orang tua yang mengejar materi (Habibi, 2007). Banyak anak TKI harus melewati masa remaja (10-15 tahun) tanpa kehadiran, kasih sayang dan bimbingan orangtua. Padahal, periode ini merupakan masa paling kritis dan menentukan bagi anakmenuju proses remaja. Perpisahan ibu dan keluarga juga berdampak kepada kondisi anak. Dalam jangka waktu yang relatif lama dapat merenggangkan bonding antara anak dan ibu sehingga menyebabkan tidak terbangunnya basic trust dan menimbulkan kesulitankesulitan tingkah laku dalam perkembangan kepribadian anak selanjutnya (Gunarsa, 2003). Basic trust dan kepribadian remaja merupakan landasan dalam perkembangan sosial anak untuk dapat menjalin hubungan dengan orang lain. Secara ekonomi, migrasi internasional berdampak positif terhadap keluarga migran, namun juga berdampak negatif khususnya terhadap kesehatan psikologis anak (Sukamdi dan Anna Marie Wattie, 2011).

Terkait dengan data diri TKI asal Kabupaten Pamekasan yang resmi tercatat didalam sistem komputerisasi tenaga kerja luar negeri (SISKO-TKLN) di BNP2TKI dalam enam tahun terakhir (2012 sampai 17 Maret 2017) sebanyak 4.294 orang, terdiri dari 2.651 Laki-laki dan 1.643 Perempuan. Yang bekerja pada sektor formal sebanyak 2.938 orang dan sektor informal 1.356 orang. Sebagian besar bekerja di Arab Saudi 2.607 orang, Malaysia 1.016 orang, Uni EmiratArab (UEA) 245 orang, dan Brunei Darussalam 140 orang. Sisanya bekerja di berbagai negara kawasan Asia Pasifik lainnya. Fenomena ini menggambarkan adanya dilema paradoks pada keluarga TKI. Disatu sisi kepergian orangtua menjadi TKI memberikan dampak positif karena pendapatan yang diperoleh TKI dapat meningkatkan kesejahteraan keluarga, termasuk dalam investasi pendidikan anak, namun disisi lain ketidak seimbangan ekosistem keluarga TKI beresiko menurunkan kualitas perkawinan, menurunkan keterampilan sosial anak, meningkatkan stres anak, dan menurunkan prestasi akademik anak akibat tidak adanya perhatian ibu terhadap anak. Orangtua punya peran yang penting dalam perkembangan. Ada berbagai gaya pengasuhan orangtua yang bisa amat berbeda-beda. Dengan semakin banyaknya orangtua yang menjadi TKI, masa depan bangsa ini dibangun di atas fondasi yang keropos. Banyak anak TKI yang karena faktor ekonomi dan kurangnya 
kesadaran tidak bisa membina pendidikan yang layak. Ini disebabkan bukan karena tidak mampunya untuk membiayai, akan tetapi karena dukungan keluarga untuk sekolah sangat kurang. Padahal pendidikan bisa menjadi tiket bagi mereka untuk memperbaiki taraf hidup (Bagus Kurniawan, 2012). Bisa dilihat bahwa terdapat perbedaan antara anak-anak di rumah tangga migran dengan nonmigran. Anak-anak pada keluarga migran lebih banyak bermasalah dengan teman sebaya dibandingkan dengan anakanak pada keluarga nonmigran. Secara psikologis, anak-anak pada rumah tangga nonmigran menyatakan lebih bahagia jika dibandingkan dengan anak-anak pada keluarga migran. Anak-anak pada rumah tangga migran cenderung lebih pasif dalam hal mengatasi masalah-masalah yang muncul, baik dalam keluarga (saudara kandung) maupun pekerjaan sekolah. Anak-anak keluarga migran menunjukkan kecenderungan untuk lebih menahan diri dan tertutup ketika mengekspresikan perasaan maupun saat mencari dukungan ataupun bantuan. Peran orang tua asuh pengganti sangat dibutuhkan untuk memimbing, memberikan saran, dan semangat bagi remaja yang ditinggal orang tuanya menjadi TKI. Berdasarkan fenomena di atas maka peneliti berkeinginan untuk melakukan penelitian dengan judul "Pola Pengasuhan Remaja Pada Keluarga Buruh Migran Indonesia (BMI) Untuk Mewujudkan Generasi Berkualitas di Kecamatan Pengantenan-Pamekasan"

\section{B. RUMUSAN MASALAH}

Dari latar belakang di atas, rumusan masalah dalam penelitian adalah "Bagaimanakah Pola Pengasuhan Remaja Pada Keluarga Buruh Migran Indonesia (BMI)
Untuk Mewujudkan Generasi Berkualitas di Kecamatan Pengantenan-Pamekasan?"

\section{TUJUAN PENELITIAN}

Mengetahui Pola Pengasuhan Remaja Pada Keluarga Buruh Migran Indonesia (BMI) Untuk Mewujudkan Generasi Berkualitas di Kecamatan PengantenanPamekasan.

\section{TINJAUAN PUSTAKA}

\section{A. Pola Asuh Orang Tua}

\section{Pengertian Pola Asuh Orang Tua}

Pola asuh terdiri dari dua kata yaitu pola dan asuh. Menurut Kamus Besar Bahasa Indonesia (2008:1088) bahwa "pola adalah model, sistem, atau cara kerja", Asuh adalah "menjaga, merawat, mendidik, membimbing, membantu, melatih, dan sebagainya" Kamus Besar Bahasa Indonesia (2008:96). Sedangkan arrti orang tua menurut Nasution dan Nurhalijah (1986:1) “Orang tua adalah setiap orang yang bertanggung jawab dalam suatu keluarga atau tugas rumah tangga yang dalam kehidupan seharihari disebut sebagai bapak dan ibu." Gunarsa (2000:44) mengemukakan bahwa "Pola asuh tidak lain merupakan metode atau cara yang dipilih pendidik dalam mendidik anak-anaknya yang meliputi bagaimana pendidik memperlakukan anak didiknya." Jadi yang dimaksud pendidik adalah orang tua terutama ayah dan ibu atau wali. Casmini (dalam Palupi, 2007:3) menyebutkan bahwa: 
hingga kepada upaya pembentukan norma-norma yang diharapkan oleh masyarakat pada umumnya."

Menurut Thoha (1996:109) menyebutkan bahwa "Pola Asuh orang tua adalah merupakan suatu cara terbaik yang dapat ditempuh orang tua dalam mendidik anak sebagai perwujudan dari rasa tanggung jawab kepada anak." Berdasarkan uraian di atas maka dapat disimpul-kan bahwa pola asuh orang tua adalah suatu proses interaksi antara orang tua dan anak, yang meliputi kegiatan seperti memelihara, mendidik, membimbing serta mendisplinkan dalam mencapai proses kedewasaan baik secara langsung maupun tidak langsung.

\section{Jenis-Jenis Pola Asuh Orang Tua}

Terdapat perbedaan yang berbeda-beda dalam mengelompokkan pola asuh orang tua daam mendidik anak, yang antara satu dengan yang lainnya hampir mempunyai persamaan. Diantaranya sebagai berikut:

Menurut Hourlock (dalam Thoha, 1996: 111-112) mengemukakan ada tiga jenis pola asuh orang tua terhadap anaknya, yakni:

1) Pola Asuh Otoriter ditandai dengan cara mengasuh anak dengan aturan-aturan yang ketat, seringkali memaksa anak untuk berperilaku seperti dirinya (orang tua), kebebasan untuk bertindak atas nama diri sendiri dibatasi.

2) Pola Asuh Demokratis ditandai dengan adanya pengakuan orang tua terhadap kemampuan anak, anak diberi kesempatan untuk tidak selalu tergantung pada orang tua.

3) Pola Asuh Permisif ditandai dengan cara orang tua mendidik anak yang cenderung bebas, anak dianggap sebagai orang dewasa atau muda, ia diberi kelonggaran seluas-luasnya untuk melakukan apa saja yang dikehendaki.

Menurut Baumrind (dalam Dariyo, 2004:98) membagi pola asuh orang tua menjadi 4 macam, yaitu:

1) PolaAsuh Otoriter (parent oriented). Ciri pola asuh ini menekankan segala aturan orang tua harus ditaati oleh anak. Orang tua bertindak semena-mena, tanpa dapat dikontrol oleh anak. Anak harus menurut dan tidak boleh membantah terhadap apa yang diperintahkan oleh orang tua.

2) Pola Asuh Permisif. Sifat pola asuh ini, children centered yakni segala aturan dan ketetapan keluarga di tangan anak. Apa yang dilakukan oleh anak diperbolehkan orang tua, orang tua menuruti segala kemauan anak.

3) Pola Asuh demokratis. Kedudukan antara anak dan orang tua sejajar. Suatu keputusan diambil bersama dengan mempertimbangkan kedua belah pihak. Anak diberi kebebasan yang bertanggung jawab, artinya apa yang dilakukan oleh anak tetap harus di bawah pengawasan orang tua dan dapat dipertanggungjawabkan secara moral.

4) Pola Asuh Situasional. Orang tua yang menerapkan pola asuh ini, tidak berdasarkan pada pola asuh tertentu, tetapi semua tipe tersebut diterapkan secara luwes disesuaikan dengan situasi dan kondisi yang berlangsung saat itu.

Menurut Baumrind (dalam King, 2010:172) bahwa orang tua berinteraksi dengan anaknya lewat salah satu dari empat cara: 
1) Pola Asuh Authoritarian

Pola asuh authoritarian merupakan pola asuh yang membatasi dan menghukum. Orang tua mendesak anak untuk mengikuti arahan mereka dan menghargai kerja keras serta usaha. Orang tua authoritarian secara jelas membatasi dan mengendalikan anak dengan sedikit pertukaran verbal.

2) Pola asuh Authoritative

Pola asuh authoritative mendorong anak untuk mandiri namun tetap meletakkan batas-batas dan kendali atas tindakan mereka. Pertukaran verbal masih diizinkan dan orang tua menunjukkan kehangatan serta mengasuh anak mereka.

3) Pola Asuh Neglectful

Pola asuh neglectful merupakan gaya pola asuh di mana mereka tidak terlibat dalam kehidupan anak mereka. Anakanak dengan orang tua neglectful mungkin merasa bahwa ada hal lain dalam kehidupan orang tua dibandingkan dengan diri mereka.

4) Pola Asuh Indulgent

Pola asuh indulgent merupakan gaya pola asuh di mana orang tua terlibat dengan anak mereka namun hanya memberikan hanya sedikit batasan pada mereka. Orang tua yang demikian membiarkan anak-anak mereka melakukan apa yang diinginkan.

Menurut Yatim dan Irwanto (1991: 96-97). Ada tiga cara yang digunakan oleh orang tua dalam mendidik anak-anaknya. Ketiga pola tersebut adalah:

1) Pola Asuh Otoriter

Pola asuh otoriter ditandai dengan adanya aturan-aturan yang kaku dari orang tua. Kebebasan anak sangat dibatasi, orang tua memaksa anak untuk berperilaku seperti yang diinginkannya. Bila aturan-aturan ini dilanggar, orang tua akan menghukum anak, biasanya hukuman yang bersifat fisik.

2) Pola Asuh Demokratis

Pola asuh demokratis ditandai dengan adanya sikap terbuka antara orang tua dengan anaknya. Mereka membuat aturan-aturan yang disetujui bersama. Anak diberi kebebasan untuk mengemukakan pendapat, perasaan, dan keinginannya dan belajar untuk dapat menanggapi pendapat orang lain.

3) Pola Asuh Permisif

Pola asuh ini ditandai dengan adanya kebebasan yang diberikan pada anak untuk berperilaku sesuai dengan keingin-annya sendiri. Orang tua tidak pernah memberi aturan dan pengarahan kepada anak. Semua keputusan diserahkan kepada anak tanpa adanya pertimbangan orang tua.

Hardy dan Heyes (1986:131) mengemukakan empat macam pola asuh yang dilakukan orang tua dalam keluarga, yaitu :

1) Autokratis (Otoriter)

Ditandai dengan adanya aturan-aturan yang kaku dari orang tua dan kebebasan anak sangat di batasi.

2) Demokratis

Ditandai dengan adanya sikap terbuka antara orang tua dan anak.

3) Permisif

Ditandai dengan adanya kebebasan pada anak untuk berprilaku sesuai dengan keinginannya sendiri. 


\section{4) Laissez faire}

Pola ini ditandai dengan sikap acuh tak acuh orang tua terhadap anaknya.

Dari berbagai macam bentuk pola asuh di atas pada intinya hampir sama. Misalnya saja antara pola asuh parent oriented, authoritarian, otoriter, semuanya menekankan pada sikap kekuasaan, kedisiplinan dan kepatuhan yang berlebihan. Demikian pula halnya dengan pola asuh authoritative atau demokratis menekankan sikap terbuka dari orang tua terhadap anak. Sedangkan pola asuh neglectful, indulgent, children centered, permisif dan laissez faire orang tua cenderung membiarkan atau tanpa ikut campur, bebas, acuh tak acuh, apa yang dilakukan oleh anak diperbolehkan orang tua, orang tua menuruti segala kemauan anak.

\section{METODE PENELITIAN}

\section{A. Jenis Penelitian}

Jenis penelitian ini adalah penelitian kualitatif dengan metode deskriptif. Penelitian ini berusaha memecahkan masalah dan menemukan pola pengasuhan orang tua pengganti. Hal ini didasarkan pada pertimbangan bahwa peneliti ingin memahami, mengkaji secara mendalam serta memaparkannya dalam tulisan ini mengenai Pola Pengasuhan Remaja Pada Keluarga Buruh Migran Indonesia (BMI) Untuk Mewujudkan Generasi Berkualitas di Kecamatan Pengantenan-Pamekasan. Karena tujuan tersebut, maka relevan jika penelitian ini dilakukan dengan menggunakan pendekatan kualitatif. Pendapat Bogdan dan Taylor (dalam Moleong: 1988: 2) menerangkan bahwa "Penelitian Kuali-tatif sebagai prosedur penelitian yang meng- hasilkan data deskriptif berupa kata tertulis atau lisan dari orang-orang atau perilaku yang dapat diamati". Menurut mereka pendekatan ini diarahkan pada latar individu tersebut secara holistik (utuh). Jadi dalam hal ini tidak boleh mengisolasikan individu atau organisasi kedalam variabel atau hipotesis tetapi perlu memandangnya sebagai bagian dari suatu keutuhan.

Berdasarkan penjelasan tersebut, diharapkan dengan adanya penelitian ini maka dapat menggambarkan tentang Pola Pengasuhan Remaja Pada Keluarga Buruh Migran Indonesia (BMI) Untuk Mewujudkan Generasi Berkualitas di Kecamatan Pengantenan-Pamekasan karena pada penelitian ini berusaha menemukan data yang berkenaan dengan fakta, fenomena yang terjadi selama proses pelaksanaan pembinaan pegawai fungsional, hambatan serta upaya dalam mengoptimalisasikan kegiatan pembi-naan tersebut.

\section{B. Lokasi Penelitian}

Sesuai dengan judul yang penulis buat maka penelitian ini akan dilakukan pada Kecamatan Pengantenan-Pamekasan.

\section{Informan Penelitian}

Informan penelitian adalah orang yang dimanfaatkan untuk memberikan informasi tentang situasi dan kondisi latar belakang penelitian (Moleong 2000: 97). Informan merupakan orang yang benar-benar mengetahui permasalahan yang akan diteliti. Dalam penelitian ini terdapat 2 informa diantaranya:

1. Informan kunci, yaitu orang-orang yang sangat memahami permasalahan yan diteliti. Adapun yang dimaksud sebagai informan kunci dalam penelitian ini adalah empat informan orang tua asuh 
yang mempunyai masa pengasuhan paling sedikit satu tahun.

2. Informan non kunci, yaitu orang yang dianggap mengetahui permasalahan yang diteliti yaitu remaja yang ditinggal orang tua kandungnya ke luar negeri paling sedikit satu tahun. Tokoh agama dan masyarakat yang ada di Kecamatan Pengantenan-Pamekasan

Data yang digunakan dalam penelitian ini adalah data primer dan data sekunder:

1. Data Primer

Data primer adalah data yang diperoleh langsung dari informan penelitian yang diperoleh melalui wawancara dengan menggunakan alat bantu seperti pedoman wawancara atau juga dengan menggunakan tape recorder atau juga dengan kertas yang sudah disiapkan sebelumnya.

\section{Data Sekunder}

Data sekunder dalam penelitian ini adalah data yang diambil secara tidak langsung dari sumber data. Data sekunder dalam penelitian ini yaitu data yang diperoleh melalui studi dokumentasi, buku-buku, surat kabar, makalah, arsip dan dokumendokumen lainnya yang berhubungan dengan pembinaan pegawai fungsional.

\section{A. Teknik dan Alat Pengumpulan Data}

Dalam mengumpulkan data yang diperlu-kan dalam penelitian ini, digunakan tekhnik pengumpulan data sebagai berikut:

1. Wawancara (interview)

Dalam pengumpulan data tentang Pola Pengasuhan Remaja Pada Keluarga Buruh Migran Indonesia (BMI) Untuk Mewujud-kan Generasi Berkualitas di Kecamatan Pengantenan Pamekasan, dilakukan wawancara dengan nara sumber yang relevan yaitu orang tua asuh TKI serta remaja yang ditingal orang tua kandungnya.

2. Dokumentasi

Dalam hal ini penulis mencari dan mempelajari dokumen-dokumen yang berhubungan dengan fokus permasalahan yang diteliti yaitu dokumen-dokumen yang berupa surat izin TKI dari pemerintah, foto, dan dokumentasi lainnya

\section{B. Uji Keabsahan Data}

Agar data yang diperoleh lebih jelas dan memiliki kekuatan validitas dan reliabilitas, maka peneliti juga melakukan wawancara terhadap tokoh masyarakat dan agama setempat. Sedangkan teknik yang penulis lakukan untuk keabsahan data pada penelitian ini adalah teknik triangulasi.

Tekhnik triangulasi yaitu tekhnik pemeriksaan keabsahan data yang memanfaatkan sesuatu yang lain diluar data yang ada, untuk keperluan pengecekan atau sebagai pembanding untuk data tersebut dan juga untuk memperkaya data. Denzin dalam Moleong (2001:178) membedakan triangulasi kedalam empat bentuk yang meliputi Triangulasi sumber, metode, penyidik dan teori. Dalam penelitian ini, hanya digunakan jenis triangulasi sumber. Maksudnya adalah, pengujian dilakukan dengan membandingkan dan mengecek balik derajat kepercayaan suatu informasi yang diperoleh melalui waktu dan alat yang berbeda. Hal ini dilakukan dengan jalan membandingkan data hasil pengamatan dengan data hasil wawancara dan membandingkan hasil wawancara dengan isi suatu dokumen yang berkaitan. 


\section{Tekhnik Analisis Data}

Analisis data adalah proses mencari dan mengatur wawancara dan catatan yang diperoleh di lapangan serta bahan- bahan lain yang telah dihimpun sehingga dapat merumuskan hasil dari apa yang telah ditemukan. Relevan dengan jenis penelitian yaitu penelitian kualitatif dengan metode deskriptif, maka tekhnik analisis yang digunakan adalah tekhnik analisis kualitatif. Data yang telah terkumpul berupa katakata dari berbagai sumber dianalisis secara intensif. Teknik Analisis data dilakukan dengan menggunakan tekhnik analisis data kualitatif, dengan melakukan analisis secara intensif terhadap data yang telah diperoleh dilapangan berupa kata-kata. Adapun langkah yang peneliti gunakan dalam menganalisis data sesuai dengan pendapat yang dikembangkan oleh Miles dan Huberman (Sugiono, 2005) :

\section{PEMBAHASAN}

Pola Asuh yang berada di kecamatan Pengantenan-Pamekasan yang ditinggal oleh orang tuanya pergi bekerja ke luar negeri terdapat banyak persepsi dan argumen dari orang tua pengganti, tokoh agama/ masyarakat dan remaja yang ditinggal oleh orang tuanya pergi bekerja keluar negeri. Berikut adalah data mengenai informasi yang didapat oleh enumerator untuk menggali dan mencari pola pengasuhan remaja pada keluarga buruh migran.

\section{Pola asuh orang tua pengganti terhadap remaja yang ditinggal orang tuanya menjadi TKI di luar negeri}

Orang tua yang seharusnya membimbing anak-anaknya untuk menjadi kepri- badian yang baik dan berguna bagi nusa dan bangsa, harus digantikan oleh orang tuas asuh dikarenakan faktor ekonomi yang kurang. Anak-anak yang beranjak dewasa mulai belajar untuk mencari jati diri dan membutuhkan panutan dan arahan agar tidak salah untuk menjadi orang dewasa yang dibutuhkan dan disanjung oleh masyarakat sekitar. Fase perpindahan pertumbuhan dari anak-anak ke dewasa disebut sebagai fase remaja, yang biasanya berada pada umur sekitar 10-21 tahun (BKKBN, 2006). Pada fase remaja peran orang tua sangat dibutuhkan dan diharapkan agar dapat memberikan arahan tentang memilih teman dan menentukan tujuan hidup.

Pengetahuan remaja tentang akil baligh atau yang biasa dikatakan "dewasa" harus diketahui oleh orang tua dan anak remaja itu sendiri. Tanda-tanda dan perilaku kehidupan sehari-hari tentang dewasa harus diberitahu oleh orang tua ke anaknya yang sudah remaja. Kekurangan informasi remaja akan "dewasa" bisa missed persepsi dan menyebabkan perkembangan remaja yang salah dan men-dekati perbuatan asusila. Orang tua harus tahu, mengerti dan paham bagaimana cara memberikan informasi "dewasa" ke anaknya yang sedang remaja. Pesan tersebut harus diterima oleh remaja disaat waktu dan ruang yang tepat sekaligus efektif.

Pola asuh orang tua memiliki karakter yang berbeda-beda dengan orang tua lainnya, begitu juga dengan keluarga yang orang tuanya sedang bekerja di luar negeri menjadi tenaga kerja Indonesia atau yang disebut sebagai Buruh Migran Indonesia (BMI). Kondisi remaja yang sedang ditinggal orang tuanya menjadi BMI akan digantikan peran orang tua nya ke orang tua pengganti 
seperti, kakek, nenek, paman, atau saudara dari ayah dan ibu nya. Pola orang tua asuh pengganti terhadap remaja yang ditinggal menjadi BMI akan mengalami perubahan psikologi, sosial dan budaya. Remaja yang diasuh langsung oleh orang tuanya dengan orang tua pengganti akan sangat berbeda perkembangan dan pertumbuhan kehidupa remaja tersebut.

Kondisi remaja yang diasuh oleh orang tua pengganti jelas akan mempengaruhi kepribadian remaja yang dapat berdampak ke negatif maupun positif. Pola asuh yang dilakukan oleh orang tua pengganti mempunyai tuntutan yang berebeda dengan orang tua asli. Hal ini terkait dengan perbedaan perlakuan orang tua terhadap remaja di lingkungan sosialnya yang mempengaruhi kehidupan sosial dan psikis remaja. Banyak faktor yang mempengaruhi pola asuh orang tua pengganti terhadap remaja yang ditinggal orang tuanya menjadi TKI (Tenaga Kerja Indonesia). Faktor-faktor tersebut akan menciptakan beberapa model dan sikap orang tua asuh dalam memperlakukan perkembangan remaja selama ditinggal orang tuanya bekerja di luar negeri. Seperti pada data kualitatif dengan responden orang tua asuh pengganti dengan minimal satu (1) tahun sudah ditinggal orang tuanya bekerja ke luar negeri, yang akan dijelaskan di halaman berikut:

Responden atas nama Halim (lakilaki yang berumur 75 tahun) yang sudah enam (6) tahun menjadi orang tua asuh pengganti di Pamekasan dari remaja yang ditinggal orang tuanya menjadi TKI. Halim adalah seorang kakek yang mengasuh cucu nya yang sudah menginjak usia remaja akibat dari anaknya yang mennjadi TKI. Tingkat pendidikan Halim lulusan Sekolah
Dasar (SD) dan bekerja sebagai buruh tani dengan jumlah anggota keluarga yang harus diberi nafkah berjumlah empat (4) orang. Pengeluaran untuk kehidupan sehari-hari perbulan berkisar dua juta rupiah. Tingkat pengeluaran ekonomi yang cukup tinggi, sehingga membutuhkan kiriman materi dari anaknya yang bekerja menjadi TKI. Pengetahuan Halim akan akil baligh atau "dewasa" hanya sekedar permukaan saja, yaitu;

"laki-laki kalau sudah dianggap dewasa akan tumbuh bulu di bagian ketiak dan kemaluan, sedangkan perempuan datang bulan atau menstruasi."

Tanda-tanda dewasa pada laki-laki dan perempuan tidak hanya sebatas tumbuh bulu halus dan menstruasi, namun masih banyak perubahan bentuk tubuh dan karakter dalam remaja tersebut. Halim hanya sekedar tahu permukaan fisik tanda-tanda remaja dari tetangga sekitar, namun masih belum mengenal lebih jauh lagi perubahan fisik dari anak-anak ke remaja. Tindakan Halim untuk menasehati cucu nya agar tidak berpacaran dan mendekati laki-laki adalah salah satu contoh pola asuh orang tua pengganti yang otoriter, untuk mencegah dari perbuatan yang tidak diinginkan (hamil sebelum nikah). Tradisi Madura untuk menikah adalah sesuatu yang ditunggu-tunggu, karena akan memperoleh saudara dan memperbanyak tali silaturahmi. Menurut Halim usia yang tepat untuk menikah adalah laki-laki berumur 17 tahun dan perempuan berumur 15 tahun. Usia yang tepat untuk menikah khusus laki-laki 25 tahun dan perempuan 21 tahun (BKKBN, 2017). Perbedaan pengetahuan usia yang tepat untuk menikah antara Halim dan BKKBN adalah satu kendala yang harus diberikan solusi dengan segera, karena masyarakat 
Madura, khususnya di Pamekasan hampir berpendapat seperti Halim, maka yang terjadi akan meledaknya pernikahan dini di Pamekasan. Hasil wawancara dengan Halim tentang informasi NAPZA, HIV/AIDS, PIK-R, genre, dan program bina keluarga TKI adalah tidak tahu sama sekali tenntang informasi tersebut. Halim tidak mengetahui apabila anak asuhnya sduah punya pacara atau belum, hanya sekedar memperingatkan saja untuk tidak pacaraan dan dekat dengan laki-laki. Orang tua kandung dari anak asuh Halim menguhubungi anaknya menggunakan handphone, sebanyak seminggu dua kali dan membahas tentang keadaan anak, sekolah anak, dan keluarga besar. Hasil kerja orang tua kandung di luar negeri ditransfer ke Halim untuk kebutuhan anaknya sebesar 500.000-1.000.000 per bulan. Kontrol keuangan diserahkan orang tua kandung ke Halim sebagai orang tua asuh pengganti. Orang tua kandung dari cucunya Halim yang menjadi TKI adalah putranya atau ayah dari cucunya. Orang tua dari cucunya Halim sudah bercerai dan sekarang telah menikah dengan perempuan di Malaysia. Pendidikan ayah dari cucunya Halim adalah SMP (Sekolah Menengah Pertama), berusia 37 tahun dan lama menjadi TKI di Malaysia adalah enam tahun. Pekerjaannya menjadi kuli bangunan di Malaysia yang sifatnya tidak tetap (serabutan) dan pulang ke Indonesia untuk mengunjungi putrinya dua kali dalam enam tahun.

Informan ke dua yang bernama Siana (perempuan berumur 55 tahun) yang bertempat tinggal di kabupaten Pamekasan, bekerja sebagai buruh tani yang tidak pernah sekolah dan mempunyai delapan anggota keluarga. Siama menjadi orang tua asuh pengganti selama empat tahun dengan jumlah pengeluaran per bulan tiga juta rupiah. Semakin banyak jumlah anggota keluarga, maka semakin tinggi pengeluaran yang dibutuhkan, sehingga salah satu keluarga harus bekerja sebagai TKI. Siana mengetahui informasi "dewasa" hanya dilihat dari lak-laki yang mempunyai jenggot dan perempuan datang bulan. Pengetahuan siana akan pertumbuhan cucunya masuk dalam era remaja hanya tanda-tanda biologis saja, seperti datang bulan dan tumbuhnya bulu di kemaluan. Sifat, karakter, dan perubahan cara pandang masih belum dirasakan oleh Siana. Bentuk pencegahan pola asuh Siana terhadap cucunya memasuki usia remaja dengan membatasi bermain berbeda jenis kelamin. Ketidak tahuan Siana akan masa subur cucunya dan usia ideal untuk menikah (menurut Siana, Laki-laki dan perempuan sama: 15 tahun) menjadi saran yang penting untuk menjalin komunikasi anatara pemerintah dan masyarakat agar lebih banyak menyebarkan pesan terkait informasi usia idela pernikahan. Televisi adalah salah satu media yang dilihat oleh Siana, sehingga informasi bahaya Napza sedikit diketahuinya. HIV/AIDS, PIK-R, Generasi Berencana, dan program bina keluarga TKI adalah informasi yang sangat penting untuk keluarga yang sedang berada di level rendah untuk tingkat pengawasan orang tua. Siana tidka mengetahui semua informasi tersebut, dikarenakan lebih focus ke pekerjaan sebagai buruh tani. Informasi cucunya sudah punya teman dekat (pacar) itu pun tidak diketahuinya. Komunikasi dijalin oleh orang tua kandung melalui handphone seminggu sekali. Materi yang dikirim dari orang tua kandung untuk remaja dikelola oleh Siana. Pesan yang disampaikan orang tua ke remaja berkaitan dengan prestasi belajar, keadaan kondisi remaja dan lingkungan keluarga. Siana hanya mengenal teman 
se lingkungan rumah cucunya dan tidak mengetahui teman-teman di luar lingkungan rumahnya. Orang tua kandung dari cucunya Siana bekerja sebagai TKI selama empat tahun di Malaysia menjadi pembantu rumah tangga dengan status perkejaan tetap. Bekerja sebagai TKI adalah pekerjaan berat karena meninggalkan keluarga di Indonesia, khusunya di Pamekasan-Madura. Anak Siana yang bekerja sebagai TKI adalah ibu dari cucunya yang sudah lama bercerai. Ibu tersebut berumur 32 tahun lulusan Madrasah Ibtidaiyah dan pulang ke Indonesia sebanyak dua kali selama empat tahun.

Pusia adalah narasumber ketiga dari orang tua asuh dari remaja yang ditinggal kerja menjadi TKI. Usia 60 tahun dengan jenis kelamin perempuan dan jenjang pendidikan terakhir sekolah dasar. Menjadi orang tua asuh selama 8 tahun, bekerja sebagai petani dengan jumlah anggota keluarga yang harus di nafkahi sebanyak tiga orang dan pengeluaran sebulan sebesar 1.500.000. Konsep "dewasa" hanya diketahui Pusia sebatas informasi kalau laki-laki tumbuh jenggot dan perempuan datang bulan. Ciri-ciri dan bentuk perubahan fisik pada usia remaja tidak disebutkan oleh Pusia. Ketakutan Pusia akan cucunya yang sudah remaja menyebabkan dibatasinya teman bermainnya, terutama tidak boleh bermain dengan laki-laki. Informasi tentang masa subur pada remaja perempuan tidak diketahui oleh Pusia, begitu juga dengan usia ideal menikah yang menyebutkan bahwa Laki-laki: 20 tahun dan perempuan: 17 tahun (seharusnya perempuan 21 tahun dan pria 25 tahun, sesuai BKKBN 2017). Istilah Napza, HIV/AIDS, PIK-R, Genre, program bina keluarga TKI masih belum didengar dan diketahui oleh Pusia sebagai orang tua asuh pengganti. Pengetahuan tentang teman dekat lawan jenis cucu Pusia masih belum diketahui secara jelas. orang tua kandung berkomunikasi menggunakan handphone ke Pusia untuk menanyakan kondisi anaknya seputar sekolah dan kesehatannya. Orang tua kandung menghubungi Pusia seminggu tiga kali. Kiriman materi dari orang tua kandung yang bekerja sebagai TKI sebanyak satu juta per bulan untuk kebutyuhan anaknya. Pusia mengenal teman-teman cucunya seputar lingkungan rumah saja dan aktifitas cucunya hanya membantu pekerjaan rumah (mencuci, masak, bersih-bersih rumah), belajar dan bermain. Orang tua kandung yang menjadi TKI adalah ibu nya dan ayah nya sudah cerai dan meninggal dunia. Usia ibu dari cucu Pusia berumur 35 tahun, tingkat pendidikan Sekolah Dasar, bekerja di Malaysia sebagai pembantu rumah tangga dan berstatus pekerja tetap di Malaysia. Ibu kandungnya pulang ke Indonesia sebanyak dua kali dalam delapan tahun.

Samnima merupakan informan keempat untuk orang tua asuh pengganti di kabupaten pamekasan. Berusia 56 tahun, jenis kelamin perempuan, tidak sekolah, pekerjaan sebagai buruh tani dan anggota keluarga sebanyak lima orang dengan pengeluaran perbulan untuk kebutuhan sehari-hari adalah 1.500.000. Samnima mengetahui informasi "dewasa" hanya dilihat dari lak-laki yang mempunyai jenggot dan perempuan datang bulan. Pengetahuan samnima akan pertumbuhan cucunya masuk dalam era remaja hanya tanda-tanda biologis saja, seperti datang bulan dan tumbuhnya bulubulu halus di beberapa bagian dalam tubuh remaja. Tindakan yang dilakukan Samnima untuk cucunya yang menginjak masa remaja adalah menasehati supaya tidak pacaran dulu. Informasi tentang masa subur di usia remaja, tidak diketahui oleh Samnima. Pengetahuan 
samnima akan usia ideal menikah adalah laki-laki : 22 tahun, dan perempuan 17 tahun. Napza dan HIV/AIDS adalah informasi yang pernah didengar oleh Samnima dari tetangga sekitar. PIK-R, generasi berencana, dan program bina keluarga TKI masih belum diketahui oleh Samnima. Tidak tahunya informasi tentang cucunya yang mempunyai kedekatan atau tidak terhadap laki-laki adalah salah satu bentuk pola asuh yang masih belum masuk kedalam ruang private anak remaja tersebut. Orang tua kandung menghubungi anaknya melalui handphone setiap hari dan menanyakan tengan keadaan dan sekolah anak. Materi yang dikirim dari orang tua kandung dikelola langsung oleh Samnima untuk kebutuhan sekolah dan hidup keluarga. Samnima mengenal temanteman sekolah cucunya hanya sebatas di lingkungan keluarga yang kebetulan satu sekolahan dengan cucunya. Samnima mengontrol cucunya dengan cara menelpon cucunya seminggu tiga kali. Aktifitas cucu kalau dirumah adalah membantu membersihkan rumah. Orang tua kandung yang menjadi TKI adalah ayah dan berumur 35 tahun bekerja sebaga kuli bangunan di Malaysia dengan status pekerjaan serabutan. Lama menjadi TKI 12 tahun dan pulang ke Indonesia sebanyak 3 kali selama 12 tahun.

Dari data keempat informan orang tua asuh pengganti yang bekerja sebagai TKI di luar negeri menurut gender laki-laki yang berjumlah satu orang dan tiga perempuan sehingga total informan empat narasumber dengan syarat informan satu tahun ditinggal orang tua kandung menjadi TKI. Umur mempengaruhi kedekatan antara informan dengan anak yang ditinggal orang tua kandungnya. Semakin tinggi umurnya, maka tingkat komunikasi semakin sering. Hal ini dikarenakan waktu luang informan di rumah lebih banyak daripada di tempat kerja. Tingkat pendidikan informan tidak berpengaruh terhadap pengetahuan akan bahaya luar dari usia remaja dan kesehatan reproduksi. Salah satu faktor yang berpengaruh orang tua asuh dalam pengetahuan tentang usia remaja adalah ruang lingkup sosial dan media yang sering diakses. Penggunaan media yang saat ini sedang overload dan sering digunakan oleh masyarakat adalah handphone dan televise. Berbagai informasi yang benar dan bohong menyebar bebas di masyarakat. Orang tua asuh pengganti sebagian besar menggunakan televisi dan komunikasi antar warga untuk memperoleh informasi tentang Napza, AIDS/HIV, dan pengetahuan kesehatan repoduksi lainnya. Ada banyak juga yang tidak tahu tentnag informasi tersebut, karena hanya bersosialisasi dengan anggota keluarga besar orang tua asuh pengganti. Kegiatan yang dilakukan oleh orang tua asuh sebagian besar mengikuti pengajian dan kegiatan yang bersifat rohaniislami. Remaja yang ditinggal oleh orang tua kandung melakukan aktivitasnya dengan cara mengerjakan tugas sekolah, membersihkan rumah, membantu orang tua asuh pengganti bekerja, dan bermain sambil belajar dengan teman di lingkungan keluarganya.

Hubungan remaja dengan orang tua asuh pengganti adalah kakek dan nenek kandung. Komunikasi yang dilakukan oleh kakek atau nenek ke orang tua kandung remaja menggunakan handphone. Intensitas kakek atau nenek yang mengasuh remaja melakukan komunikasi dengan orang tua kandung tinggi, hampir rata-rata seminggu melakukan komunikasi dengan orang tua kandung yang berada di luar negeri. Kepulangan orang tua kandung ke Indonesia untuk menjenguk anaknya yang sudah remaja hampir diatas 4 tahun selama satu 
atau dua kali saja. Rasa empati, peduli dan saying orang tua kandung ke anaknya dapat dilakukan melalui handphone, meskipun kepulangan orang tua kandung tidak bisa diprediksi. Perekonomian orang tua asuh pengganti masih dibawah rata-rata dengan mata pencaharian sebagai petani. Pengeluaran satu bulan rata-rata 1.500 .000 dengan penghasilan petani yang tidak menentu karena factor harga padi yang fluktuatif dan kondisi cuaca alam yang tidak menentu. Bantuan ekonomi dari orang tua kandung yang menjadi TKI sangat diharapkan oleh kakek atau nenek yang menjadi orang tua pengganti. Factor umur yang akhirnya mempengaruhi tingkat pengetahuan tentang tanda-tanda usia remaja pada anak asuhnya. Hampir seluruh informan hanya mengetahui tanda-tanda remaja seputar perubahan fisik. Perubahan psikis dan bentuk sosialisasi dengan teman yang berbeda jenis kelamin masih belum diketahui oleh orang tua asuh pengganti.

\section{Respon Remaja terhadap pola asuh orang tua pengganti yang ditinggal orang tua kandungnya menjadi TKI di luar negeri}

Informan pertama berjenis kelamin perempuan. Informan ini bernama Yanti, yang sudah berusia 15 tahun. Informan saat ini duduk di bangku Sekolah menengah pertama kelas 3. Informan di tinggal oleh orang tuanya pada saat duduk di kelas 3 SD dan pada saat itu berumur 9 tahunan, jadi informan di tinggal sudah 6 tahunan. Informan memiliki barang-barang sekunder seperti smartphone, sepeda motor, laptop dan lainlain. Dalam berteman dengan sebayanya di lingkungan rumahnya informan mempunyai sahabat yang bernama Robiyatul adawiyah.
Selain di sekolah maupun di rumah, informan lebih banyak bergaul dengan tetangga yakni teman sebayanya serta keluarga yakni kakek dan adiknya. Biasanya Informan kalau mempunyai masalah di sekolahan atau pun pelajaran entah itu keuangan maupun masalah pribadi temannya,informan bercerita dan minta pendapat maupun bantuan dengan Sahabatnya. Informan setelah ditinggal orang tua (ayah ataupun ibunya) pergi ke luar negeri, informan lebih dekat dengan kakek dan adiknya. Informan tidak mengikuti kegiatan di lingkungan sekolah maupun rumah seperti pramuka, Osis, karang taruna maupun remaja masjid. Terkait kegiatan di rumah sehari-hari informan membantu tugas rumah, belajar dan bermain layaknya anak seumurannya. Informan juga mengetahui tanda-tanda akil baliq untuk laki-laki dan perempuan baik secar fisik maupun psikis nya seperti kalau laki-laki ada jenggotnya dan kalau perempuan menstruasi. Informan juga mengetahui bahwa hal yang harus dilakukan dan dihindari ketika remaja sudah mulai akil baliq ialah tidak terlalu dekat dengan laki-laki karena takut hamil. Mendengar kata hamil, informan juga mendengar kalo pada kehamilan pasti adanya masa subur. Informan juga mengetahui bahwa usia ideal laki-laki dan perempuan menikah yakni perempuan minimal 21 tahun dan laki-laki minimal 25 tahun. Informan juga pernah mendengar kata NAPZA yakni narkotika, alkohol, psikotropika, dan zat adiktif) di sebuah berita tayangan di televisi. Infoman juga mengetahui bahwa mengkonsumsi NAPZA yang dilakukan terus menerus dapat merusak bagian tubuh atau kesehatan. Terkait tentang penyakit akibat dari seks bebas seperti HIV /AIDS informan mengetahuinya dan cara pencegahannya tidak mengetahui tapi mengetahui bahayanya 
bisa menyebabkan meninggal dunia. Terkait tentang pengetahuan remaja yang terrencana, yakni Informan juga tidak penah mendengar PIK-R (Pusat informasi dan konsultsi remaja) dan Informan juga tidak pernah mendengar kata genre (Generasi berencana). Dalam hal pengaksesan internet kebiasaan informan yakni mendownload lagu dan browsing materi tentang sekolahnya . Informan juga tidak sedang mengkonsumsi obat-obatan terlarang seperti NAPZA yakni narkotika, alkohol, psikotropika, dan zat adiktif) untuk bersenang-senang. Informan juga tidak sedang berpacaran. Terkait ditinggalnya informan sebagai anak oleh orang tuanya saat ini yakni perasaan Informan juga mempunyai rasa sedih karena tidak dapat bertemu dengan kedua orang tuanya dan senangnya dapat uang yang cukup lebih. Harapan kedepan informan Cuma satu yakni supaya cepat pulang orang tuanya dan bisa berkumpul kembali dengan keluarganya yang utuh. Terkait pendidikan, ketrampilan, pekerjaan, menikah yakni Informan ingin meneruskan pendidikan ke jenjang yang lebih tinggi. Informan juga mengetahui bahwa pengertian perilaku positif yaitu tingkah laku yang tidak nakal dan menuruti apa kata orang tua yang terbaik baginya dan kalau perilaku nehatif yakni perilaku yang nakal seperti mencuri dan lain-lain. Terkait prestasi di sekolah Informan juga terbilang siswa yang rajin dan berprestasi baik di luar maupun dalam seperti selalu mendapatkan peringkat dua dan tiga selama ini dan prestasinya di luar yakni pernah ikut lomba ngaji dan puisi.

Informan kedua berjenis kelamin perempuan. Informan ini bernama Kurrotul Aini, yang sudah berusia 15 tahun. Informan saat ini duduk di bangku Sekolah menengah pertama kelas 3. Informan di tinggal oleh orang tuanya pada saat duduk di kelas 1
SD dan pada saat itu berumur 7 tahunan, jadi informan di tinggal sudah 8 tahunan. Informan memiliki barang-barang sekunder seperti smartphone, sepeda motor, laptop dan lain-lain. Dalam berteman dengan sebayanya di lingkungan rumahnya informan mempunyai sahabat yang bernama Yanti. Selain di sekolah maupun di rumah, informan lebih banyak bergaul dengan tetangga yakni teman sebayanya serta keluarga yakni kakek dan adiknya. Biasanya Informan kalau mempunyai masalah di sekolahan atau pun pelajaran entah itu keuangan maupun masalah pribadi temannya, informan bercerita dan minta pendapat maupun bantuan dengan Sahabatnya satu sekolahnya yang bernama Siti rusniati. Informan setelah ditinggal orang tua (ayah ataupun ibunya) pergi ke luar negeri, informan lebih dekat dengan nenek dan adiknya. Informan mengikuti kegiatan di lingkungan sekolah maupun rumahnya yakni pramuka dan Palang merah remaja. Terkait kegiatan di rumah sehari-hari informan membantu tugas rumah, belajar dan bermain layaknya anak seumurannya. Informan juga mengetahui tanda-tanda akil baliq untuk laki-laki dan perempuan baik secar fisik maupun psikis nya seperti kalau laki-laki suaranya berubah menjadi lebih keras dan kalau perempuan menstruasi. Informan juga mengetahui bahwa hal yang harus dilakukan dan dihindari ketika remaja sudah mulai akil baliq ialah menjaga diri kepada lawan jenisnya. Terkait kehamilan, informan juga mendengar kalo pada kehamilan pasti adanya masa subur yakni setelah menstrusi itu masa subur. Informan tidak mengetahui bahwa usia ideal laki-laki dan perempuan menikah yakni perempuan minimal 21 tahun dan laki-laki minimal 25 tahun, informan menyatakannya laki-laki 20 tahun dan perempuan 17 tahun. Informan juga pernah mendengar 
kata NAPZA yakni narkotika, alkohol, psikotropika, dan zat adiktif). Infoman juga mengetahui bahwa mengkonsumsi NAPZA yang dilakukan terus menerus dapat merusak bagian tubuh atau kesehatan dan stress. Terkait tentang penyakit akibat dari seks bebas seperti HIV /AIDS informan mengetahuinya dan cara pencegahannya yakni jangan gonta-ganti pasangan. Terkait tentang pengetahuan remaja yang terrencana, yakni Informan juga tidak penah mendengar PIK-R (Pusat informasi dan konsultsi remaja) dan Informan juga tidak pernah mendengar kata genre (Generasi berencana). Dalam hal pengaksesan internet kebiasaan informan yakni membuka facebook dan browsing dengan opera mini. Informan juga tidak sedang mengkonsumsi obat-obatan terlarang seperti NAPZA yakni narkotika, alkohol, psikotropika, dan zat adiktif) untuk bersenang-senang. Informan juga tidak sedang berpacaran dan tidak pernah pacaran. Terkait ditinggalnya informan sebagai anak oleh orang tuanya saat ini yakni perasaan Informan juga mempunyai rasa sedih karena tidak dapat bertemu dengan kedua orang tuanya dan senangnya dapat uang yang cukup lebih. Harapan kedepan informan Cuma satu yakni supaya semoga sehat selalu dan panjang umur. Terkait pendidikan, ketrampilan, pekerjaan, menikah yakni Informan ingin meneruskan pendidikan ke jenjang yang lebih tinggi yakni kuliah, sukses dan menikah. Informan juga mengetahui bahwa pengertian perilaku positif yaitu tingkah laku yang berkumpul dengan teman seperti silaturrahmi dan kalau perilaku negatif yakni perilaku yang pacaran yang tidak sehat. Terkait prestasi di sekolah Informan juga terbilang siswa yang rajin dan berprestasi baik di luar maupun dalam seperti selalu mendapatkan juara lomba IPA
(Ilmu pengetahuan alam), selama ini dan prestasinya di luar yakni pernah ikut lomba ngaji jus`amma di Banyuannyar.

Informan ketiga berjenis kelamin perempuan. Informan ini bernama Nurul Laili, yang sudah berusia 14 tahun. Informan saat ini duduk di bangku Sekolah menengah pertamakelas 2. Informan ditinggal oleh orang tuanya pada saat duduk di kelas 5 SD dan pada saat itu berumur 11 tahunan, jadi informan di tinggal sudah 4 tahunan. Informan memiliki barang-barang sekunder seperti smartphone, sepeda motor, laptop, sepeda mini dan lainlain. Dalam berteman dengan sebayanya di lingkungan rumahnya informan mempunyai sahabat yang bernama Khairun Nisak. Selain di sekolah maupun di rumah, informan lebih banyak bergaul dengan tetangga yakni teman sebayanya bernama Yuni serta keluarga yakni kakek dan adiknya. Biasanya Informan kalau mempunyai masalah di sekolahan atau pun pelajaran entah itu keuangan maupun masalah pribadi temannya, informan bercerita dan minta pendapat maupun bantuan dengan Sahabatnya satu sekolahnya yang bernama Khairun Nisak. Informan setelah ditinggal orang tua (ayah ataupun ibunya) pergi ke luar negeri, informan lebih dekat dengan nenek paman dan tantenya. Informan tidak mengikuti kegiatan di lingkungan sekolah maupun rumahnya seperi pramuka dan Palang merah remaja maupun lainnya. Terkait kegiatan di rumah sehari-hari informan membantu tugas rumah, membantu nenek berjualan, belajar dan bermain layaknya anak seumurannya. Informan juga mengetahui tanda-tanda akil baliq untuk laki-laki dan perempuan baik secar fisik maupun psikis nya seperti kalau laki-laki suaranya berubah menjadi lebih keras dan kalau perempuan menstruasi. Informan juga mengetahui bahwa hal yang harus dilakukan dan dihindari ketika 
remaja sudah mulai akil baliq ialah menjauhi perilaku pacaran. Terkait kehamilan, informan juga mendengar kalo pada kehamilan pasti adanya masa subur yakni setelah haid itu masa subur. Informan mengetahui bahwa usia ideal laki-laki dan perempuan menikah yakni perempuan minimal 21 tahun dan lakilaki minimal 25 tahun, Informan juga pernah mendengar kata NAPZA yakni narkotika, alkohol, psikotropika, dan zat adiktif lainnya). Infoman juga mengetahui bahwa mengkonsumsi NAPZA yang dilakukan terus menerus dapat menghabiskan uang orang tuanya. Terkait tentang penyakit akibat dari seks bebas seperti HIV /AIDS informan mengetahuinya dan bahayanya bisa membunuh dirinya sendiri. Terkait tentang pengetahuan remaja yang terrencana, yakni Informan juga tidak penah mendengar PIK-R (Pusat informasi dan konsultsi remaja) dan Informan juga tidak pernah mendengar kata genre (Generasi berencana). Dalam hal pengaksesan internet kebiasaan informan yakni membuka facebook. Informan juga tidak sedang mengkonsumsi obat-obatan terlarang seperti NAPZA yakni narkotika, alkohol, psikotropika, dan zat adiktif) yang hanya untuk bersenang-senang. Informan juga tidak sedang berpacaran dan tidak pernah pacaran. Terkait ditinggalnya informan sebagai anak oleh orang tuanya saat ini yakni perasaan Informan juga biasa saja, karena sudah terbiasa dan sukanya di kirimi uang dan dukanya tidak ada. Harapan kedepan informan Cuma satu yakni cepat sukses dan bisa cepat berkumpul lagi dengan keluarga.

Informan keempat berjenis kelamin perempuan. Informan ini bernama Nuril Istianah yang sudah berusia 14 tahun. Informan saat ini duduk di bangku Sekolah menengah pertama kelas 3 . Informan di tinggal oleh orang tuanya pada saat berumur
2 tahun, jadi informan di tinggal sudah 14 tahunan. Informan memiliki barang-barang sekunder seperti smartphone, sepeda motor, laptop dan lain-lain. Dalam berteman dengan sebayanya di lingkungan rumahnya informan mempunyai sahabat yang bernama Uun. Selain di sekolah maupun di rumah, informan lebih banyak bergaul dengan tetangga yakni teman sebayanya serta keluarga yakni nenek dan adiknya. Biasanya Informan kalau mempunyai masalah di sekolahan atau pun pelajaran entah itu keuangan maupun masalah pribadi temannya,informan bercerita dan minta pendapat maupun bantuan dengan Sahabatnya bernama uun tersebut. Informan setelah ditinggal orang tua (ayah ataupun ibunya) pergi ke luar negeri, informan lebih dekat dengan nenek dan adiknya. Informan tidak mengikuti kegiatan di lingkungan sekolah maupun rumah seperti pramuka, Osis, karang taruna maupun remaja masjid. Terkait kegiatan di rumah sehari-hari informan membantu tugas rumah, belajar dan bermain layaknya anak remaja seumurannya. Informan juga mengetahui tanda-tanda akil baliq untuk laki-laki dan perempuan baik secara fisik maupun psikis nya seperti kalau laki-laki yakni junub dan kalau perempuan yakni menstruasi. Informan juga mengetahui bahwa hal yang harus dilakukan dan dihindari ketika remaja sudah mulai akil baliq ialah menjauhi yang maksiat. Terkait masalah hamil, informan juga mendengar kalo pada kehamilan pasti adanya masa subur dan informan paham kalau masa subur saat menstruasi. Informan juga mengetahui bahwa usia ideal laki-laki dan perempuan menikah yakni perempuan minimal 21 tahun dan laki-laki minimal 25 tahun. Informan juga pernah mendengar kata NAPZA yakni narkotika, alkohol, psikotropika, dan zat adiktif) di sebuah berita tayangan di 
televisi. Infoman juga mengetahui bahwa mengkonsumsi NAPZA yang dilakukan terus menerus dapat membunuh dirinya sendiri. Terkait tentang penyakit akibat dari seks bebas seperti HIV /AIDS informan mengetahuinya bahwa penyakit tersebut bisa menular dan cara penyegahannya yakni tidak mengonta-ganti pasangan. Terkait tentang pengetahuan remaja yang terrencana, yakni Informan juga tidak penah mendengar PIK-R (Pusat informasi dan konsultsi remaja) dan Informan juga tidak pernah mendengar kata genre (Generasi berencana). Dalam hal pengaksesan internet kebiasaan informan yakni mendownload lagu dan browsing tugas tentang sekolahnya. Informan juga tidak sedang mengkonsumsi obat-obatan terlarang seperti NAPZA yakni narkotika, alkohol, psikotropika, dan zat adiktif) untuk bersenang-senang. Informan juga tidak sedang berpacaran. Terkait ditinggalnya informan sebagai anak oleh orang tuanya saat ini yakni perasaan Informan tidak tahu karena masih kecil pada waktu itu. Harapan kedepan informan Cuma satu yakni supaya sehat dan selamat selama di tempat perantauan sana. Terkait pendidikan, ketrampilan, pekerjaan, menikah yakni Informan ingin meneruskan pendidikan ke jenjang yang lebih tinggi yakni kuliah dan bisa bekerja yang mapan. Informan juga mengetahui bahwa pengertian perilaku positif yaitu tingkah laku yang tidak nakal dan menyalahi aturan yang ada dan kalau perilaku nehatif yakni perilaku yang nakal seperti mencuri dan lain-lain.

Remaja yang diasuh oleh orang tua pengganti yang ada di pamekasan mempunyai karakter penurut, suka membantu orang tua pengganti, belajar rohani tentang keislaman sangat menjadi prioritas utama, tidak bersosialisasi dengan remaja yang berbeda jenis kelamin, prestasi yang cukup memuaskan karena mempunyai jadwal sendiri untuk belajar dan bermain, teman bermain dari lingkungan rumah setempat saja.

\section{Respon Tokoh agama/masyarakat terhadap fenomena keluarga yang meninggalkan anaknya bekerja menjadi Tenaga Kerja Indonesia}

Informan dari tokoh agama ini bernama Ahmad Zairi. Saat ini Informan berusia 35 tahun berpendidikan Starta satu yang bertempat tinggal di Desa Plakplak. Informan mengetahui adanya keluarga-keluarga di kampungnya yang bekerja di luar negeri. Informan menyatakan bahwa biasanya pekerja TKIyang mempunyai anak, anaknya dititipkan ke kakek atau neneknya . Informan juga tidak mengetahui adanya perkumpulan keluarga Buruh Migran Indonesia. Sebagai Tokoh agama sekaligus masyarakat, Informan juga berpesan terhadap keluarga yang mengasuh remaha yang ditinggal orang tuanya ke luar negeri, Hal tersebut disampaikannya saat pengajian yang berbunyi beberapa pesan agar menghubungi keluaga yang ada di malasia atau luar negeri dan menyuruhnya untuk selalu ingat kepada Allah SWT dan jangan sampai putus komunikasi terus sambung silaturahmi terhadap keluarganya. Informan juga tidak mengetahui bahwa adanya program atau kegiatan yang menangani pembinaan remaja di lingkungannya. Informan berpendapat keluarga yang ditinggal orang tuanya bekerja di luar negeri sejauh ini masih bagus. Menurut Informan pengasuhan remaja dari keluarga BMI yakni lebih memberikan nasehat yang baik dan mengajarkan hal-hal yang baik dan memberikan yang terbaik jika mampu. Informan juga memberikan saran kepada keluarga BMI agar agar bisa tumbuh dan berkembang baik sesuai dengan usianya 
sebaiknya di pondokan saja dikarenakan sesuai ada yang mengawasi disana dan di sibukan dengan kegiatan positif seperti ngajingaji dan hafalan surat-surat ayat suci Al qur`an.

Informan dari tokoh agama ini bernama Kiai Ali Wafa. Saat ini Informan berusia 41 tahun berpendidikan sekolah menengah atas yang bertempat tinggal di Desa Plakplak Ds Pangantenan. Informan mengetahui adanya keluarga-keluarga di kampungnya yang bekerja di luar negeri.. Informan juga tidak mengetahui adanya perkumpulan keluarga Buruh Migran Indonesia. Sebagai Tokoh agama sekaligus masyarakat, Informan juga berpesan terhadap keluarga yang mengasuh remaja yang ditinggal orang tuanya ke luar negeri, Hal tersebut disampaikannya saat pengajian yang berbunyi beberapa pesan agar tidak lupa sholat, selalu ingat keluarga, dan selalu komunikasi tidak terputus. Informan juga tidak mengetahui bahwa adanya program atau kegiatan yang menangani pembinaan remaja di lingkungannya. Informan berpendapat keluarga yang ditinggal orang tuanya bekerja di luar negeri sejauh ini masih biasa saja. Menurut Informan pengasuhan remaja dari keluarga BMI yakni lebih memberikan yang terbaik baik berupa pendidikan moral maupun agama. Informan juga memberikan saran kepada keluarga BMI agar bisa tumbuh dan berkembang baik sesuai dengan usianya sebaiknya selalu menghubungi keluarga yang ada di malaysia (luar negeri), menasehati dan di masukkan ke pondok agar menjadi remaja yang berakhlak baik dan berbudi pekerti luhur yang berguna bagi masyarakat.

Tokoh agama dan masyarakat di Pame-kasan mempunyai jadwal untuk menyeleng-garakan pengajian yang isinya memberikan tauziyah kepada masyarakat agar tetap menjaga komunikasi dengan orang tua yang menjadi TKI dan jangan lupa untuk mendoakannya agar tetap sehat dan ingat kepada tuhan yang maha esa. Lingkungan pondok pesantren di kecamatan Pengantenan-Pamekasan mempe-ngaruhi tidanakan, sifat dan perilaku remaja untuk tidak menentang orang yang lebih tua (dalam hal ini adalah orang tua pengganti), sehingga apapun yang diaktakan oleh kakek atau nenek sebagai orang tua pengganti, maka remaja yang ditinggal orang tuanya menjadi TKI akan menuruti dengan senang hati, tanpa ada beban.

\section{Respon Remaja terhadap pola asuh orang tua pengganti}

\section{Informan bernama Yanti}

Informan berjenis kelamin Perempuan. Informan bernama Yanti. Informan saat ini berusia 15 Tahun dan sedang duduk di bangku sekolah menegah pertama kelas 3 . Dalam pengelolaan keuangan, Infoman dalam kesehariannya diberikan uang saku sebesar sepuluh ribu rupiah. Respon dari Informan saat diberikan uang saku sepuluh ribu rupiah adalah menerima apa adanya apapun yang diberikan orang tua penggantinya. Informan pernah menginginkan sebuah barang tetapi tidak cukup dalam materi membelinya dan sikap informan ialah diam saja, karena nanti pada akhirnya orang tua pengganti juga mengerti apa yang informan butuhkan. Dalam segi pendidikan informan suka kalau belajar di tunggui disampingnya oleh orang tua pengganti yakni kakeknya. Terkait prestasi hasil belajar, informan selalu rangking di kelas dari rangking 2 sampai dengan 3. Informan juga selalu disiplin dalam pengerjaan tugas dari sekolah 
karena informan mengetahui bahwa itu kewajiban bagi pelajar yang sedang belajar dan informan sebagai pelajar harus bisa memotivasi dirinya untuk mengejar cita cita informan untuk menjadi seorang guru. Dalam pergaulan sehari-hari Informan tidak pernah memilih-milih teman, semuanya informan berteman. Informan juga senang dalam bermain handphone. Informan juga memiliki karakteristik yang mandiri dalam pemenuhan kebutuhan dari informan. Informan juga paham dengan cara bersosial yang baik yakni tidak memusuhi teman bila tidak sepaham pemikiran dan pendapat. Informan juga menyadari dan tidak memberontak serta menuruti bila orang tua pengganti menyuruh tidak boleh main di luar.

\section{Informan bernama Nurul laili,}

Informan berjenis kelamin Perempuan. Informan bernama Nurul laili. Informan saat ini berusia 14 Tahun dan sedang duduk di bangku sekolah menegah pertama kelas 2. Dalam pengelolaan keuangan, Infoman dalam kesehariannya diberikan uang saku tidak menentu paling besar sebesar delapan ribu rupiah. Respon dari Informan saat diberikan uang saku delapan ribu rupiah adalah marah kepada orang tua penggantinya. Informan tidak tersinggung bila orang tua penggantinya bertanya tentang uang harian yang diberikan oleh informan. Dalam segi pendidikan informan suka kalau belajar di tunggui disampingnya oleh orang tua pengganti yakni neneknya. Terkait prestasi hasil belajar, informan selalu bersyukur bahwa informan selalu rangking 2 di kelas. Informan juga selalu disiplin dalam pengerjaan tugas dari sekolah karena informan mengetahui bahwa itu kewajiban bagi pelajar yang sedang belajar dan informan sebagai pelajar harus bisa memotivasi dirinya untuk mengejar cita cita informan untuk melanjutkan berkuliah. Dalam pergaulan sehari-hari Informan memilihmilih teman yang mau diajak mengerjakan tugas dari sekolahnya dengan berbarengan atau kerja kelompok. Informan juga senang dalam bermain handphone. Informan juga memiliki karakteristik yang kurang mandiri dalam pemenuhan kebutuhan dari informan, seperti meminta tolong ke temannya apabila informan membutuhkan sesuatu. Informan juga paham dengan cara bersosial yang baik yakni tidak memusuhi teman bila tidak sepaham pemikiran dan pendapat. Informan juga menyadari dan tidak memberontak serta menuruti bila orang tua pengganti menyuruh untuk tidak boleh main di luar.

\section{Informan bernama Kurrotul Aini}

Informan berjenis kelamin Perempuan. Informan bernama Kurrotul Aini. Informan saat ini berusia 15 Tahun dan sedang duduk di bangku sekolah menegah pertama kelas 3. Dalam pengelolaan keuangan, Infoman dalam kesehariannya diberikan uang saku sebesar lima belas ribu rupiah. Respon dari Informan saat diberikan uang saku lima belas ribu rupiah adalah bersyukur dan kalau kurang bisa meminta lagi ke orang tua pengganti informan. Informan tidak tersinggung bila orang tua penggantinya bertanya tentang uang harian yang diberikan oleh informan. Infoman kalaupun menginginkan sesuatu mencoba untuk menahannya dulu sampai uang informan mencukupi untuk membelinya dengan cara menabung. Dalam segi pendidikan informan suka kalau belajar di tunggui disampingnya oleh orang tua penggantinya apa lagi ditunggui oleh orang tua yang aslinya. Terkait prestasi hasil 
belajar, informan selalu bersyukur bahwa informan selalu rangking 1 di kelas dan pernah mengikuti lomba IPA. Informan juga selalu disiplin dalam pengerjaan tugas dari sekolah karena informan mengetahui bahwa itu kewajiban bagi pelajar yang sedang belajar dan informan sebagai pelajar harus bisa memotivasi dirinya untuk mengejar cita cita informan untuk melanjutkan berkuliah dan ingin menjadi orang yang sukses. Dalam pergaulan sehari-hari Informan tidak memilih-milih teman menurutnya semuanya informan berteman. Informan juga senang dalam bermain handphone. Informan juga memiliki karakteristik yang kurang mandiri dalam pemenuhan kebutuhan dari informan, seperti meminta tolong ke temannya apabila informan membutuhkan sesuatu. Informan juga paham dengan cara bersosial yang baik yakni tidak memusuhi teman bila tidak sepaham pemikiran dan pendapat. Informan juga menyadari dan tidak memberontak serta menuruti bila orang tua pengganti menyuruh untuk tidak boleh main di luar asal ingat waktunya kalo waktunya main dan waktu di rumah.

\section{Informan bernama Nuril Istianah}

Informan berjenis kelamin Perempuan. Informan bernama Kurrotul Aini. Informan saat ini berusia 14 Tahun dan sedang duduk di bangku sekolah menegah pertama kelas 3. Dalam pengelolaan keuangan, Infoman dalam kesehariannya diberikan uang saku sebesar sepuluh ribu ribu rupiah. Respon dari Informan saat diberikan uang saku sepuluh ribu rupiah adalah bersyukur dan kalau kurang bisa meminta lagi ke orang tua pengganti informan dan kalau nenek tidak mempunyai uang ya infoman diam saja tidak berani meminta. Informan tidak tersinggung bila orang tua penggantinya bertanya tentang uang harian yang diberikan oleh informan. Infoman kalaupun menginginkan sesuatu mencoba untuk menahannya dulu sampai uang informan mencukupi untuk membelinya dengan cara menabung. Dari segi pendidikan informan suka kalau belajar di tunggui disampingnya oleh orang tua penggantinya yakni neneknya. Terkait prestasi hasil belajar, informan selalu bersyukur bahwa informan selalu rangking 2 di kelas. Informan juga selalu disiplin dalam pengerjaan tugas dari sekolah karena informan mengetahui bahwa itu harus dikerjakan bagi pelajar yang sedang belajar dan informan sebagai pelajar harus bisa memotivasi dirinya untuk mengejar cita cita informan untuk ingin menjadi orang yang sukses. Dalam pergaulan sehari-hari Informan tidak memilih-milih teman, siapapun bisa berteman dengan informan.. Informan juga senang dalam bermain handphone. Informan juga memiliki karakteristik yang mandiri dalam pemenuhan kebutuhan dari informan. Informan juga paham dengan cara bersosial yang baik yakni tidak memusuhi teman bila tidak sepaham pemikiran dan pendapat dikarenakan setiap orang pasti mempunyai pandangan yang berbeda-beda. Informan juga menyadari dan tidak memberontak serta menuruti bila orang tua pengganti menyuruh untuk tidak boleh main di luar, asalka informan ingat waktunya kalo waktunya main dan waktu di rumah.

\section{KESIMPULAN}

Umur mempengaruhi kedekatan antara informan dengan anak yang ditinggal orang tua kandungnya. Semakin tinggi umurnya, maka tingkat komunikasi semakin sering. Hal ini dikarenakan waktu luang informan di rumah lebih banyak daripada di 
tempat kerja. Tingkat pendidikan informan tidak berpengaruh terhadap pengetahuan akan bahaya luar dari usia remaja dan kesehatan reproduksi. Salah satu faktor yang berpengaruh orang tua asuh dalam pengetahuan tentang usia remaja adalah ruang lingkup sosial dan media yang sering diakses. Penggunaan media yang saat ini sedang overload dan sering digunakan oleh masyarakat adalah handphone dan televisi. Berbagai informasi yang benar dan bohong menyebar bebas di masyarakat. Orang tua asuh pengganti sebagian besar menggunakan televise dan komunikasi antar warga untuk memperoleh informasi tentang Napza, AIDS/ HIV, dan pengetahuan kesehatan repoduksi lainnya. Ada banyak juga yang tidak tahu tentang informasi tersebut, karena hanya bersosialisasi dengan anggota keluarga besar orang tua asuh pengganti.

\section{Saran :}

Sosialisasi tentang tanda-tanda usia remaja adalah salah satu tugas pekerjaan rumah yang harus diselesaikan oleh pemerintah kabupaten Pamekasan agar masyarakat nya, terutama dikecamatan Pengantenan paham dan mengerti dewasa dalam konteks laki-laki dan perempuan. Pengetahuan tentang bahaya NAPZA juga harus terus disosialisasikan oleh Pemerintah kabupaten setempat agar remaja-remaja yang ditinggal orang tuanya bekerja keluar negeri dapat arahan dan saran agar menjauhi obat-obatan terlarang tersebut.

\section{DAFTAR PUSTAKA}

Al-Qur'an Al-Karim, QS. Al-Baqarah ayat 220

Dariyo, A. (2004). Psikologi Perkembangan Remaja. Bogor: Ghalia Indonesia

Dekrita Sari Yakut. 2005.Analisis faktor-faktor yang mempengaruhi keputusan konsumen dalam membeli produk industry garmen. Journal penelitian. Fakultas Ekonomi Universitas Udayana Bali

Gunarsa, S.D. 2003. Psikologi Perkembangan. Jakarta: BPK Gunung Mulia

Gunarsa, S.D. (2000). Azas psikologi Keluarga Idaman, Jakarta: BPK Gunung Mulia

Habibi, Muazar. 2007. Program Bimbingan Bagi Orangtua dalam Penerapan Pola Asuh Anak untuk Meningkatkan Kematangan Sosial Anak. Studi Kasus. Program Bimbingan dan Konseling Sekolah Pasca Sarjana Universitan Pendidikan Indonesia.

Hardy M. dan Heyes S. (1986). Pengantar Psikologi. Alih Bahasa: Soenardji Jakarta: Erlangga

King, L. A. (2010). Psikologi Umum: Sebuah Pandangan Apresiatif. Jakarta: Salemba Humanika

Moleong, L. J. (2011). Metodologi Penelitian Kualitatif (Edisi Revisi). Bandung: Remaja Rosdakarya Offset.

Singgih D, Gunarsa. 2003. Psikologi Perkembangan. Jakarta ; BPK Gunung Mulia.

Sugiyono. (2010). Metode Penelitian Bisnis. Bandung: Alfabeta.

Thoha, C. (1996). Kapita Selekta Pendidikan Islam. Yogyakarta : Pustaka Pelajar (IKAPI) 


\section{Sumber Jurnal :}

Palupi, D. R. (2013). Hubungan Antara Motivasi Berprestasi dan Persepsi Terhadap Pola Asuh Orangtua Dengan Prestasi Belajar Psikologi Angkatan 2010 Universitas Airlangga Surabaya. Jurnal Psikologi Pendidikan dan Perkembangan. Vol. 2, No. 01

\section{Sumber Internet :}

http://www.bnp2tki.go.id/read/12288/P4TKIPamekasan-Bersama-DisnakertransSosialisasikan-Pentingnya-MenjadiTKI-Prosedural diakses tanggal 1 januari 2018 